\title{
CONSERVATION STATUS OF PLANT COMMUNITIES AT ULMANN POINT AND COMANDANTE FERRAZ ANTARCTIC STATION AREA, ADMIRALTY BAY, KING GEORGE ISLAND, ANTARCTICA, BASED ON THE INDEX OF ECOLOGICAL SIGNIFICANCE
}

http://dx.doi.org/10.4322/apa.2014.026

\author{
Filipe de Carvalho Victoria ${ }^{1, *}$, Margéli Pereira de Albuquerque ${ }^{2}$, Antonio Batista Pereira ${ }^{2}$ \\ 'Plants Genomics Center, Universidade Federal de Pelotas - UFPel, Capão do Leão, RS, Brazil \\ ZUniversidade Federal do Pampa - UNIPAMPA, São Gabriel, RS, Brazil \\ *e-mail: filipevictoria@gmail.com
}

Abstract: The aim of this study has been to research the conservation status of the plant communities in ice-free areas of Ullmann Point and Comandante Ferraz Antarctic Station vicinities, Admiralty Bay, King George Island, Antarctica. The study started with the classification and description of the plant communities based primarily on phytosociological and biodiversity data. The coverage degree and frequency of each species found was used to calculate the index of ecological significance. At Ullmann Point 12 plant species were found in higher frequency, when at Ferraz beach only 9 highly frequent species were found. The most important species in both studied areas were Sanionia uncinata (Hedw.) Loeske. Syntrichia princeps and Bryum pseudotrichetrum were found associated with the most important species at Ullmann Point and Ferraz Station beach respectively. These results have demonstrated the fragility of plant communities in Maritime Antarctica, based on the low frequency and coverage of moss species known in this area.

Keywords: Antarctic mosses conservation, ice-free areas, plant communities

\section{Introduction}

Considering the physiognomy and the floral composition of plant communities of the Admiralty Bay ice-free areas $\left(62^{\circ} 03^{\prime} 40^{\prime \prime}-62^{\circ} 05^{\prime} 40^{\prime \prime} \mathrm{S}\right.$ and $\left.58^{\circ} 23^{\prime} 30^{\prime \prime}-58^{\circ} 24^{\prime} 30^{\prime \prime} \mathrm{W}\right)$, evidence has been found that these communities are very different from those identified in other islands of Maritime Antarctica. In Antarctica, summer is short and cold, with a maximum temperature around zero ${ }^{\circ} \mathrm{C}$. During this period, permanent rainy periods and strong snow precipitations are common (Rakusa-Suszczewski et al., 1993). For Pereira and Putzke (1994), these conditions, along with those imposed by a long dark winter, also create limitations for the occurrence of plant species in the region, especially flowering plants, since such conditions inhibit the reproductive cycle. For this reason, only two species of flowering plants are known in Antarctica, Deschampsia antarctica Desv. and Colobanthus quitensis Kunth. On the other hand, moss and lichen species are more adaptable, so much so that they have developed well in polar conditions being the main representative plants of Antarctica (Putzke \& Pereira, 2001). The moss formations are most expressive and complex in ice-free areas, occurring mainly in tufts and carpets at lower levels such as beach and drainage lines (Victoria et al., 2009), but moss cushion species can be observed on rocky outcrops of marine emerged tablelands 
(Schaeffer, 2004) as well on rocks next to bird colonies (Pereira \& Puztke, 1994).

In order to complement the knowledge of plant communities in the ice-free areas of Admiralty Bay, communities of lichens and mosses observed during a phytosociologic study of the region are described. A status of conservation of these species based on the coverage and frequency of most representative species sampled are presented.

\section{Materials and Methods}

During the 2004/2005 austral summer, plant communities in the vicinities of Comandante Ferraz Station, beside the Cousteau Whale's, and at Ullmann Point beach were studied. This study started from the phytosociological survey, using Braun-Blanquet (1932) quadrats method, adapted to Antarctic conditions (Kanda, 1986). After throwing c.a 160 quadrats of $25 \times 25 \mathrm{~cm}$, within an altitude gradient varying from sea level up to about $150 \mathrm{~m}$ high. Whenever possible, samples of lichens with highly developed ascomas (presence of apothecia or perithecia) were made. Saxicolous species were collected with the help of a geologists' hammer, and muscicolous and/or terricolous species, with the help of a knife, to guarantee that individuals would collect them with some substrate. High coverage moss species or dominant lichen species were also sampled. Identification of the species was based on the work of Redon (1985), Ochyra (1998), Pereira and Putzke (1994) and Putzke and
Pereira (1990). The index of ecological significance (IES) was calculated based in the Lara and Mazimpaka (1998), as follows: IIE $=F(1+C)$, where: $F$ is the relative frequency of the species in the area or habitat (generated by the number of occurrences (x) divided by the total number of samples considered (n): $\mathrm{F}=100 \mathrm{x} / \mathrm{n}$. $\mathrm{C}$ is the average coverage of the specie in the samples: $\mathrm{C}=\Sigma(\mathrm{ci}) / \mathrm{x}$; where ci is the cover class and $\mathrm{x}$, the number of sampling points in which the species occur.

\section{Results and Discussion}

It was possible to verify the occurrence of 4 moss species in the adjoining area of Comandante Ferraz Station (Table 1) and 9 moss species at Ullmann Point beach (Table 2) such as the most frequent species considering the 58 moss species found in Admiralty Bay. The lichen Psoroma cinnamomeum Malme was verified as being the most frequent lichen. The two flowering plants know in Antarctica were observed at lower frequencies when compared with the most frequent species found in both studied areas.

However with the IES of each species it was possible to verify that most of them can be easily seen in the area, in despite of the lower coverage (IES > 50). Compared with other initiatives these two areas are less complex, with a lower number of species in higher abundance and coverage (Ochyra, 1998; Victoria et al., 2009). These results can be representative of the sensibility of these plant communities to environmental changes, since this species was found in

Table 1. The most frequent species found in Comandante Ferraz Antarctic Station vicinities. $\mathrm{C}=$ average coverage. $\mathrm{F}=$ frequency for each species in all samples. IES = Index of ecological significance.

\begin{tabular}{|c|c|c|c|}
\hline Species & $C^{(*)}$ & $F(\%)$ & IES \\
\hline Bryum pseudotriquetrum (Hedw.) Schwaegr. & 1 & 68.18 & 136.36 \\
\hline Hennediella heimii (Hedw.) Zand. & 0.28 & 22.72 & 27.89 \\
\hline Syntrichia saxicola (Card.) Zand. & 0.09 & 9.09 & 9.91 \\
\hline Sanionia uncinata (Hedw.) Loeske & 3.59 & 95.45 & 438.22 \\
\hline Deschampsia antarctica Desv. & 0.36 & 36.36 & 49.58 \\
\hline Colobanthus quitensis Kunth. & 0.09 & 13.63 & 14.87 \\
\hline Leptogium sp. & 0.02 & 4.54 & 4.64 \\
\hline Psoroma cinnamomeum Malme & 0.18 & 18.18 & 21.48 \\
\hline
\end{tabular}

${ }^{\star}$ Coverage classes - 1(1-10\%), 2(11-25\%), 3(26-50\%), 4(51-75\%) and 5(75-100\%). 
Table 2. The most frequent species found at UImann Point. $\mathrm{C}=$ average coverage. $\mathrm{F}=$ frequency for each species in all samples. IES $=$ Index of ecological significance.

\begin{tabular}{|c|c|c|c|}
\hline Species & $\mathbf{C}^{(*)}$ & $F(\%)$ & IES \\
\hline Bryum dichotomum Hedw. & 0.03 & 5 & 5.18 \\
\hline Bryum orbiculatifolium Card. Et Broth. & 0.15 & 15 & 17.25 \\
\hline Bryum pseudotriquetrum (Hedw.) Schwaegr. & 0.63 & 32.5 & 53.21 \\
\hline Brachythecium austrosalebrosum (C. Muell.) Kindb. & 0.05 & 5 & 5.25 \\
\hline Polytrichastrum alpinum (Hedw.) G.L.Smith & 0.27 & 17.5 & 22.31 \\
\hline Syntrichia princeps (De Not.) Mitt & 0.91 & 60 & 114.75 \\
\hline Syntrichia saxicola (Card.) Zand. & 0.17 & 10 & 11.75 \\
\hline Sanionia uncinata (Hedw.) Loeske & 1.82 & 70 & 197.75 \\
\hline Deschampsia antarctica Desv & 0.57 & 40 & 63 \\
\hline Polytrichum juniperinum Hedw & 0.07 & 7.5 & 8.06 \\
\hline Colobanthus quitensis Kunth. & 0.21 & 22.5 & 27.28 \\
\hline Psoroma cinnamomeum Malme & 0.41 & 30 & 42.37 \\
\hline
\end{tabular}

${ }^{*}$ Coverage classes - 1(1-10\%), 2(11-25\%), 3(26-50\%), 4(51-75\%) and 5(75-100\%).

small patches and populations, indicating lower resistance and resilience. Whenever the relationships within the organisms was reduced (Schaefer et al. 2004), the impacts in these species were subject to irreversibility (Victoria \& Pereira, 2007).

For example, we can cite the most frequent Bryum species found. Bryum pseudotriquetrum (Hedw.) Schwaegr. and Bryum orbiculatifolium Card. Et Broth. Depends on ice melting found in the water lines in the austral summer (Allison \& Lewis-Smith 1973; Kanda 1986). B. pseudotrichetrum showed a high abundance in our samples and can be considered a lower degree threatened species compared to $B$. orbiculatifolium. The size of B. pseudotrichetrum population provides a better response in the case of fast environmental changes, perhaps indicating better adaptative success related of a higher coverage level (Lewis-Smith 2001).

Ochyra (1998) reports Sanionia uncinata (Hedw.) Loeske and Polytrichastrum alpinum (Hedw.) G.L.Smith as the most abundant moss species in the Maritime Antarctic, being at lower risk of threats compared with other moss species in this area. For Ullmann Point and Comandante Ferraz beach the latter was also observed only for first species. $S$. uncinata occurred in higher frequency and coverage, in the proximity of Ferraz this species being the most frequent in the plant communities, occurring in $95 \%$ of samples and having an average of $50 \%$ coverage in each sample. At Ullmann Point this species occurs with a $70 \%$ frequency and has a mean coverage of $25 \%$ per sample. For this reason this species can be considered the most important in studied plant communities (IES/Ferraz $=438.22$; IES/Ullmann = 197.75). These results were also encountered by Victoria and Pereira (2007) for the Arctowski region and Hennequin Point $($ IES $=215.20$ and IES $=153.54$, respectively). $P$. alpinum was found in other areas of Admiralty Bay being the second most important species (Ochyra, 1998; Victoria \& Pereira 2007; Victoria et al., 2009), but in the present study the latter did not occur, in that these species were encountered only at Ullmann Point in a lower frequency (17\%). B. pseudotrichetrum, for Ferraz beach, and Syntrichia princeps (De Not.) Mitt, for Ullmann Point were recorded as the second most important species for each area (IES = 136.36 and IES $=114.75$, respectively), perhaps because of the lower complexity of these two plant communities sampled, whereby these communities consist mainly of fellfield species, like these two species mentioned (Victoria et al., 2004). 
The others frequent moss species were found as important species for the plant communities at Hennequin Point and in the Arctowski region (Victoria \& Pereira, 2007), except for Hennediela heimii (Hedw.) Zand, which was encountered in higher frequency in Ferraz beach in the present study compared with other areas.

All moss species, as well as the land biota found in Admiralty Bay, were directly and indirectly affected by human presence. The maintenance of scientists and military personnel inside and outside of research stations, shelters and camps, involves a high consumption of fossil combustibles and produces high amounts of residues, creating unclear impacts in Antarctica wildlife (ATCPs 1993; Olech 1996).

This study demonstrates the fragility of moss formation in the in ice-free areas of Maritime Antarctica. A descriptive data bank can collaborate towards the continued monitoring of plant communities, contributing to the conservation of plant species in Admiralty Bay area. The phytossociological studies can contribute to the management of scientific activities related to the Brazilian Antarctic Program.

\section{References}

Allison, J.S. \& Lewis-Smith, R.I. (1973). The vegetation of Elephant Island, South Shetland Islands. British Antarctic Survey Bulletin, 33-34: 185-212.

ATCPs. (1993). Protocol on Environmental Protection to the Antarctic Treaty, with Annexes. Polar Record, 29(170): 256-75.

Braun-Blanquet, J. (1932). Plant Sociology: The study of plant communities. New York, McGraw-Hill.

Kanda, H. (1986). Moss communities in some ice-free areas along the Söya Coast, East Antarctica. Memoirs of Natural. Institute of Polar Research, Special Issue. 44: 229-40.

Lara, F. \& Mazimpaka, V. (1998). Sucession of epiphytic bryophytes in a Quercus pyrenaica forest from Spanish Central Range (Iberian Peninsula). Nova Hedwigia, 67: 125-38.

Lewis-Smith, R. I. (2001). Plant Colonisation Response to climate change in the Antarctic. Folia Fac. Sci. nat. Univ. Masarykianae Brunensis, Geográica, 25: 19-33.

Ochyra, R. (1998). The moss flora of King George Island Antarctica. Polish Academy of Sciences. Cracow.

Olech, M. (1996). Human impact on terrestrial ecosystems in West Antarctica. Proccedings of NIPR Symposium on Polar Biology, 9: 299-306

Pereira, A.B. \& Putzke, J. (1994). Floristic composition of Stinker Point. Elephant Island, Antarctica. Korean Journal of Polar Research, 5(2): 37-47.

Putzke, J. \& Pereira, A.B. (1990). Mosses of King George Island. Pesquisa Antártica Brasileira. 2(1): 17-71.

Putzke, J. \& Pereira, A.B. (2001) The Antarctic Mosses with special reference to the Shetland Island. Canoas, Ed. ULBRA.

Rakusa-Suszczewski, S.; Mietus, M. \& Piasecki, J. (1993). Weather and Climate. In: Rakusa-Suszczewski, S. (Ed.) The Maritime Antarctic Coastal Exosystem of Admiralty Bay, Departamente of Antarctic Biology, Polish Academy of Sciences.

Redón, J. (1985). Líquenes Antárticos. Instituto Antártico Chileno (INACH), Santiago de Chile.

Schaefer, C.E.G.R.; Dias, L.E.; Albuquerque, M.A.; Francelino, M.R.; Costa, L.M. \& Ribeiro, J.R.E.S. (2004). Monitoramento ambiental e avaliação dos impactos nos ecossistemas terrestres da Antártica Marítima: Princípios e aplicação. In: Schaefer, C.E.G.R.; Simas, F.N.B.; Filho, M.R.A. (Eds.). Ecossistemas costeiros e monitoramento ambiental da Antártica Marítima. Baía do Almirantado, Ilha Rei George. Viçosa, NEPUT. 
Victoria, F.C. \& Pereira, A.B. (2007). Índice de valor ecológico (IES) como ferramenta para estudos fitossociológicos e conservação das espécies de musgos na Baia do Almirantado, Ilha Rei George, Antártica Marítima. Oecologia Brasiliensis, 11(1): 50-55

Victoria, F.C.; Pereira, A.B. \& Costa, D.P. (2004). Characterization of plant communities in ice-free areas adjoining the Polish Station H. Arctowski, Admiralty Bay, King George Island, Antarctic. Actas del V ${ }^{\circ}$ Simposio Argentino y $1^{\circ}$ Latinoamericano sobre Investigaciones Antárticas 2004, Resúmen Expandido № 202BB.

Victoria, F.C.; Pereira, A.B. \& Costa, D.P. (2009). Composition and distribution of mos formations in the ice-free areas adjoining the Arctowski region, Admiralty Bay, King George Island, Antarctica. Iheringia Série Botânica, 64(1): 81-91. 